\title{
STRENGTH, RELIABILITY, AND LIFE OF AEROSPACE AND POWER ENGINEERING STRUCTURES
}

\author{
Institute of Technical Mechanics \\ of the National Academy of Sciences of U kraine and the State Space Agency of U kraine \\ 15 Leshko-Popel St., D nipro 49005, Ukraine; e-mail: hudramovich@i.ua
}

\begin{abstract}
This paper gives a brief overview of investigations into the strength, reliability, and life of aerospace and power engineering structures conducted along the following reseach line of the Institute of Technical mechanics of the National Academy of Sciences of Ukraine and the State Space Agency of Ukraine: the strength, reliabiliyty, and optimization of mechanical systems, launch vehicle, and spacecraft. The basic literature sources of 1991-2021 are cited. A more detailed consideration is given to the results obtained in 2014-2021 and published (monographs, articles indexed in international citation databases, and international conference papers). They involve the simulation of deformation of inhomogeneous material, in particular concrete, in heat-and-power engineering structures, the life estimation of shell structures of rocket/space hardware in the presence of stress concentrators in the form of openings, inclusions, and cracks, and the development of a methodological basis for the strength, reliability, and life of launch complexes for launch vehicles of different spacecraft classes. The methodological stages of calculation are considered, and high-intensity thermomechanical loads are classified. The life of launch complexes is determined using the notion of low- and high-cycle fatigue. Consideration is given to the development of fast projection-iteration schemes of the finite-element method and the method of local variations, which significantly reduce the computational time and may be used to advantage when a large body of calculations is needed in the design and development of new aerospace hardware and power engineering structures with the use of experiments at the developmental stage. In doing so, the effect of inelastic deformations in the vicinity of cutouts is analyzed. A numerical simulation of the strength and stability of inhomogeneous shell structures with the use of the above-mentioned new computational schemes is considered. Investigations of this type first of all involve inhomogeneous thin-walled shell structures at local loads and the effect of reinforcing inclusions on stress and strain concentration.
\end{abstract}

Keymords strength, reliability, life, power engineering, launch vehicles, launch complexes, inhomogeneous shell structures.

1. Hudramovich V. S., Demenkov A. F. Elastoplastic Structures with Shape Imperfections and Residual Stresses. Kyiv, 1991. 174 pp. (in Russian).

2. Pereverzev E. S. Damage Accumulation Models in Durability Problems. Kyiv, 1995. 354 pp. (in Russian).

3. Pereverzev E. S.,Daniev Yu. F. Testing and Reliability of Engineering Systems. Dnipropetrovsk: Institute of Technical Mechanics of the National Academy of Sciences of Ukraine and the State Space Agency of Ukraine, 1999. 223 pp. (in Russian).

4. Hudramovich V. S. Creep Theory and its Applications to Thin-Walled Structural Component Analysis. Kyiv, 2005. 224 pp. (in Russian).

5. Aksenenko A. V., Hudramovich V. S., Dziuba A. P., Kozlov A. K. Serviceability of Shell Structures Under Local Shock Loading. Dnipropetrovsk, 2006. 216 pp. (in Russian).

6. Daniev Yu. F., Bigus G. A. Technical Diagnostics of Hazardous Manufacturing Entities. Moscow, 2010. 415 pp. (in Russian).

7. Bigus G. A., Daniev Yu. F., Bystrova N. A., Galkin D. I. Diagnostics of Engineering Facilities Moscow, 2014. 616 pp. (in Russian). 
8. Hudramovich V. S., Dziuba A. P., Selivanov Yu. M. Holographic Interferometry in the Mechanics of Inhomogeneous Thin-Walled Structures. Dnipro, 2017. 288 pp. (in Russian).

9. Hudramovich V. S., Skalskyi V. R., Selivanov Yu. M. Holographic and Acoustic Emission Diagnostics of Inhomogeneous Structures and Materials. Lviv, 2017. 488 pp. (in Ukrainian).

10. Bigus G. A., Daniev Yu. F., Bystrova N. A., Galkin D. I. Basics of Diagnostics of Engineering Facilities and Structures. 2nd Edition. Moscow, 2018. 445 pp. (in Russian).

11. Mathematical and Computer Modeling of Engineering Systems: Collective monograph. V. S. Hudramovich (Ed.). Riga, Latvia, 2020. 164 pp.

12. udramovich V. S. Plastic and creep instability of shells with initial imperfections. Solid Mechanics and its Applications. V. 64. G. M. L. Gladwell (Ed.). Dordrecht, Boston, London, 1997. Pp. 277-289. https://doi.org/10.1007/0-306-46937-5 23

13. udramovich V. S., Lebedev A. A., Mossakovsky V. I. Plastic deformation and limit states of metal shell structures with initial shape imperfections. Light-Weight Steel and Aluminium Structures.

Proceedings Jnt. Conf. (Helsinki, Finland, 1999). P. Makelainen (Ed.). Amsterdam, Lousanne, New York, Tokyo, 1999. Pp. 257-263.

https://doi.org/10.1016/B978-008043014-0/50133-5

14. Lebedev A. A., Kosarchuk V. V., Hudramovych V. S. Micro- and macrostructural mechanics of metastable steels. Solid Mechanics and its Applications. V. 62. G. M. L. Gladwell (Ed.). Dordrecht, Boston, London. 1999. Pp. 355-362.

15. Gudramovych V. S., Gaiduchenko A. P., Kovalenko A. I. Electroforming-based technologies for manufacturing antenna-waveguide and solar power devices. Kosm. Nauka Tehnol. 2001. V. 7. No. 2/3. Pp. 66-77. (in Russian).

https://doi.org/10.15407/knit2001.02.066

16. Hudramovich V. S. Features of nonlinear deformation and critical states of shell systems with geometrical imperfections. Int. Appl. Mech. 2006. V. 42, No. 12. p. 1323-1355.

https://doi.org/10.1007/s10778-006-0204-y

17. Hudramovych V. S., Demenkov A. F., Egorov E. A., Reprintsev A. V. On the influence of the technology of manufacturing on the load-bearing capacity of steel tanks. Strength of Materials. 2006. V. 38. No. 4. Pp. $423-427$.

https://doi.org/10.1007/s11223-006-0060-3

18. Hudramovych V. S. Contact mechanics of shell structures under local loading. Int. Appl. Mech. 2009. V. 45. No. 7. Pp. 708-729.

https://doi.org/10.1007/s10778-009-0224-5

19. Hudramovych V. S., Hart E. L., Ryabokon' S. A. Plastic deformation of nonhomogeneous plates. J. Math. Eng. 2013. V. 78. No. 1. Pp. 181-197. https://doi.org/10.1007/s10665-010-9409-5

20. Hudramovich V. S., Hart E. L., Klimenko D. V., Ryabokon' S. A. Mutual influence of openings on strength of shell-type structures under plastic deformation. Strength of Materials. 2013. V. 45. No. 1. Pp. 1-9. 
21. Poshyvalov V. P., Borshchevska D. H., Riabchyi V. D., Telehina I. I. Increasing AMg6M alloy durability by energy treatment under creep conditions. Fizyko-Khimichna Mekhanika Materialiv. 2013. No. 6. Pp. 62-67. (I Ukrainian).

22. Hudramovich V. S., Levin V. ., Samarskaja E. V., Shabelnik S. V. Modeling of the deformation process of concrete based on a modified version of the theory of flow. Strength of Materials. 2014. V. 46. No. 5. Pp. 595-600. https://doi.org/10.1007/s11223-014-9587-x

23. Hart E. L., Hudramovich V. S. Projection-iterative schemes for the realization of the finite element method in problems of deformation of plates with holes and inclusions. Journ. of Mathematical Sci. 2014. V. 203. No. 1. Pp. 55-69. https://doi.org/10.1007/s10958-014-2090-x

24. Hudramovich V. S. Simulation of solar concentrator dynamics and strength. Science, Technology and Innovative Technologies in the Prosperous Epoch of Powerful State. International conference proceedings. (Ashgabat, Turkmenistan, 2015). Ashgabat: Ylym, 2015. Pp. 148-149. (in Russian).

25. Degtyarev A. V., Pylypenko O. V., Gudramovych V. S., Sirenko V. N., Daniev Yu. F., Klimenko D. V., Poshivalov V. P. About the classification of launch equipment of the space launch systems for the strength standards justification. Kosm. Nauka Tehnol. 2016. V. 22. No. 1. Pp. 3-14. (in Russian). https://doi.org/10.15407/knit2016.01.003

26. Hudramovich V. Contact interactions and limit states of the shell-type structures under local loading. Proceedings of 2016 China-Ukraine Forum on Science and Technology (Harbin, China, 2016). Harbin, 2016. Pp. 2-3.

27. Hudramovich V. S., Reprintsev A. V. Riabokon S. A. Samarskaia E. V. Life estimation of rocket/space hardware structures with consideration for the effect of stress concentrators in the form of openings. Technical Diagnostics and Non-Destructive Testing. 2016. No. 2. Pp. 28-36. (in Russian). https://doi.org/10.15407/tdnk2016.02.03

28. Doyar ., Poshyvalov V. Development of a stochastic model of failure of structural materials in creep at hardening stage. Eastern-European Journ. of Enterprise Technologies. 2016. V. 3. No. 5 (81). Pp. 25-31.

https://doi.org/10.15587/1729-4061.2016.69653

29. Gudramovich V. S., Gart E. L., Strunin K. A. Modeling of the behavior of plane-deformable elastic media with elongated elliptic and rectangular inclusions. Materials Science. 2017. V. 52. No. 6. Pp. 768-774. (in Russian). https://doi.org/10.1007/s11003-017-0020-z

30. Hudramovich V. S., Klymenko D. V., Hart E. L. Influence of cutouts on strength of cylindrical compartments of launch vehicles at inelastic deformation of material. Space Sci. \& Technol. 2017. V. 23. Pp. 6. . 12-20. (in Russian). https://doi.org/10.15407/knit2017.06.012

31. Topical Problems in Continuum Mechanics and Structural Strength. Proceedings of the International Scientific and Technical Conference in Commemoration of Acad. V. I. Mossakocsky's 100th Birthday Anniversary. Polyakov M. V. (Chf. Ed.). Hudramovich V. S., Loboda V. V., and 
Khaminich O. V. (Dep. Chf. Eds.). Dnipro, 2019. 340 pp. (in Ukrainian).

32. Hart E. L., Hudramovich V. S. Application of the projection-iterative scheme of the method of local variations to solving stability problems for thin-walled shell structures under localized actions. Strength of Materials. 2018. V. 50. No. 6. Pp. 852-858. https://doi.org/10.1007/s11223-019-00031-6

33. Hudramovich V. S., Sirenko V. N., Daniev Yu. F., Klimenko D. V., Hart E. L. Development of the normative framework methodology for justifying the residual resource of starting buildings constructions of space launch vehicles. Strength of Materials. 2019. V. 51. No. 3. Pp. $333-340$. https://doi.org/10.1007/s11223-019-00079-4

34. Hudramovich V. S., Hart E. L., Marchenko . . . Reinforcing inclusion effect on the stress concentration within the spherical shell having an elliptical opening under uniform internal pressure. Strength of Materials. 2020. V. 52. No. 6. Pp. 832-842.

https://doi.org/10.1007/s11223-021-00237-7

35. Hart E. L., Hudramovich V. S. Projection-iterative schemes for the implementation of variation-grid methods in the problems of elastoplastic deformation of inhomogeneous thin-walled structures. Journ. of Mathematical Sci. 2021. V. 254. No. 1. Pp. 21-38.

https://doi.org/10.1007/s10958-021-05285-7

36. Hart E. L., Hudramovich V. S. On the application of projection-iterative modifications of variational grid methods to the solution of elastoplastic problems in the mechanics of structurally inhomogeneous systems. Elasticity and Anelasticity. Proceedings of the International Symposium on Deformable Body Mechanics in Commemoration of A. A. llyushin's 110th Birthday Anniversary. Moscow, 2021. Pp. 226234. (in Russian). 